Canadian University Music Review

Canadian University Music Review

Revue de musique des universités canadiennes

\title{
Two Fauré Sources in the Deutsche Staatsbibliothek, East Berlin
}

\section{Edward Phillips}

Volume 11, numéro 1, 1991

URI : https://id.erudit.org/iderudit/1014832ar

DOI : https://doi.org/10.7202/1014832ar

Aller au sommaire du numéro

Éditeur(s)

Canadian University Music Society / Société de musique des universités canadiennes

ISSN

0710-0353 (imprimé)

2291-2436 (numérique)

Découvrir la revue

Citer cet article

Phillips, E. (1991). Two Fauré Sources in the Deutsche Staatsbibliothek, East Berlin. Canadian University Music Review / Revue de musique des universités canadiennes, 11(1), 89-100. https://doi.org/10.7202/1014832ar

All Rights Reserved (C Canadian University Music Society / Société de musique des universités canadiennes, 1991
Ce document est protégé par la loi sur le droit d'auteur. L'utilisation des services d’Érudit (y compris la reproduction) est assujettie à sa politique d'utilisation que vous pouvez consulter en ligne.

https://apropos.erudit.org/fr/usagers/politique-dutilisation/ 


\title{
TWO FAURÉ SOURCES IN THE DEUTSCHE STAATSBIBLIOTHEK, EAST BERLIN
}

\author{
Edward Phillips*
}

On 14 October 1924, three weeks before his death on 4 November, Gabriel Fauré wrote to his wife:

In Paris I shall spend a little of each day giving you, for consignment to the flames, all my sketches, all my rough drafts, all the bits and pieces of which I want nothing to survive me. This is something that preoccupied me very much when I was ill. You shall help me to accomplish it. (Nectoux, 1984: $338)^{1}$

This request, together with Fauré's habit of giving away manuscripts to friends, has resulted in the survival of very few primary sources for his music. Of the sketches, there survive those for Fauré's last work, the String Quartet, Op. 121, as well as seven small pocket notebooks with material for a number of works including the Requiem, various songs and piano pieces, the Second Piano Quartet, and the opera Pénélope. Autograph manuscripts of complete works do survive from all periods of Fauré's life, from the songs Op. 1, Nos. 1 and 2 (in the Bibliothèque Nationale and the Pierpont Morgan Library, respectively) to the last movement of the Trio, Op. 120, in the library of the University of Chicago. (McKay, 182). These sources (very often fair copies intended as presentation copies or as final copies for the engraver) provide much of the information that can be gleaned about Fauré's compositional method; the scholar will find clues in careful examination of layers of entry, erasures, and measures crossed out and discarded.

The bulk of this primary material for the study of Fauré's music resides in the Bibliothèque Nationale in Paris; other manuscript items are included in the collections of the Harry Ransom Center for Humanities Research at the University of Texas at Austin, the Pierpont Morgan Library, and the university libraries of Yale, Harvard, McGill, Chicago, Stanford, and the Eastman School of Music, as well as in private collections such as that of the Goüin family at Royaumont

* The author wishes to thank the Social Sciences and Humanities Research Council of Canada for a grant enabling the research required for this paper.

1 This letter is not contained in the original French edition of Fauré's correspondence (Nectoux, $\left.1980^{\mathrm{a}}\right)$. 
Abbey north of Paris. To this list can now be added the Deutsche Staatsbibliothek of East Berlin.

Included in the collection of the Musikabteilung of that library are a variety of sources related to the life and music of Gabriel Fauré. Some of this materialnotably ten letters by Fauré to André Beaunier, Jeanne Raunay, and others-has received attention in the scholarly literature (Nectoux, 1984: 363), but two items have not. The first of these is an autograph manuscript of Fauré's "La Fée aux Chansons" (Op. 27, no. 2) whose presence in Berlin is, evidently, not generally known in spite of its having been acquired by the Deutsche Staatsbibliothek (then the Royal Library) at auction in March of 1913, long before the composer's death. ${ }^{2}$ According to the auction catalog also in the possession of the Deutsche Staatsbibliotehk, the manuscript was offered for sale between 27 and 29 March of 1913 by the antiquarian dealer Leo Liepmannssohn of Berlin, and was part of a lot which included music autographs from the estates of Josef Viktor Widmann, of Felix Mottl (Privy Councillor and court Opera Director), and of A. W. Gottschalg (Court Organist). ${ }^{3}$ Nectoux and Orledge give 1882 as the year of composition and 1883 as the publication date (Nectoux, 1980: 426; Orledge, 1979: 286); and Nectoux supports this dating with the evidence of a letter from Fauré to Henriette Fuchs dated 19 September 1882:

I shall have the honour of bringing to you in Paris a little song that I have composed for you and that I now ask permission to dedicate to you. (Nectoux, 1984: 109)

It may be that the manuscript now in Berlin was given to Mme. Edmond Fuchs by Fauré, but it has been possible to substantiate neither this idea nor an intermediate provenance between Fauré or Mme. Fuchs and one of the estates involved in the 1913 sale.

The manuscript consists of two bifolia stitched with endpapers into a library folder. The music paper is that used often by Fauré and bears the embossed stamp of H. Lard-Esnault-Bellamy, Paris, ${ }^{4}$ in the upper left corner of recto pages. The manuscript measures 34 by 27 centimeters but was probably trimmed from the paper's usual size of 35 by 27 centimeters when it was placed in its library

${ }^{2}$ Robert Orledge does not include this manuscript in his list of sources (Orledge, 1979: 272-318); and while Jean-Michel Nectoux's observation that "les deux mélodies de l'op. 27 ... sont en fa majeur ..." (Nectoux, 1990: 187) is certainly true concerning the keys of the two songs as published, it may also indicate that he was unaware of the existence of this manuscript source in E major.

3 The entry in the auction catalog (p. 98) reads:

2017. Fauré (Gabriel), compositeur distingué français (né en 1845). Manuscrit de musique autogr. signé avec dédicace autogr.: La Fée aux chansons. Partition piano et chant. 4 pages $1 / 2$, in fol.

Composition d'un poème d'Armand Silvesre: "Il était une fée d'herbe ... "; datée villerville, 16 Sept. 1882. L'adresse de la dédicace sur le titure est raturée.

${ }^{4}$ I am indebted to Prof. Sabina Ratner of Vanier College, Montréal, for information about this particular company. 
binding. The manuscript is not in the excellent condition of other Faure autographs and had at one time been folded lengthwise. Page 1 recto is a title page. In pencil in the upper left are the library's call numbers ("Mus ms. autogr. Fauré (Gabriel) M 1913.568"); the manuscript is paginated in pencil in the upper right on odd pages throughout, beginning with the title page. Between is a stray, slur-like marking in blue pencil. Slightly below is an erasure; that it was the name, then destroyed of Mme. Edmond Fuchs, the dedicatee, is suggested by the remaining small marks to either side of the erasure: the preposition, "à," to the left and a mark which was probably the tail of the final "s" of "Fuchs" to the right. The erasure was done with considerably more violence then normally used by Fauré-indeed, the paper is perforated as a result. Surviving below is Fauré's inscription and his signature, both in the usual black ink. The inscription offers an insight into Fauré's sense of humour; the text of the inscription, "Souvenir affectueux d'un pris de rhum," represents an elaborate play on words which moves from the expression, "une prise de vin," through "une prise de rhum" and "un pris de rhum," to the implied, "un prix de Rome."5

In the center of the page, the title of the song and the attribution of the text to Armand Silvestre are inscribed in pencil in an unknown hand-possibly that of an engraver-that one sees elsewhere in Faure manuscripts in similar situations. Toward the lower right is the notation, "Vitterville I6 Septembre 1882"; the "6" is written over a "5." Finally, at the bottom of the page are the stamps of the publisher, Maison Hamelle (oval, blue), and of the Royal Library ("Ex Bibl. Regia Berlin"; circular, red). Pages 1 verso through 3 verso contain the score; pages 4 recto and 4 verso are blank.

There are certain differences between the autograph and published versions of the piece. The most obvious disagreement is in the key: the song appears in the manuscript in E major; in publication, it is the transposition in F major which is termed "ton original." As for tempo, the published indication is "Allegretto vivo" with a metronome setting of 160; the manuscript specifies simply, "Allegro." Further, in the manuscript the "molto meno mosso" of measure 62 and the "tempo I" of measure 76 are both omitted.

There are also a number of changes of pitch throughout the manuscript; these alterations whether erasure or overwritings can be classed in three broad categories. There are changes which correct what are almost certainly slips of the pen; there are emendations which reflect the care with which Fauré applied his craft to even the smallest foreground detail; and there are, apparently finally, small foreground changes which have a relationship with deeper levels of structure.

An example of the first type of correction can be seen in measure 9 (Example 1). On the downbeat of this measure in the left hand of the accompaniment, Faure

5 I am indebted to Profs. Leonard Adams and Daniel Chouinard of the Department of French Studies, the University of Guelph, for this observation. 


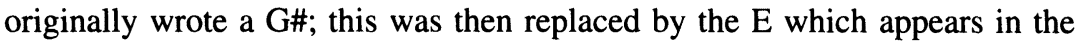
published version of the song. This seems clearly to have been no more than an error of copying.

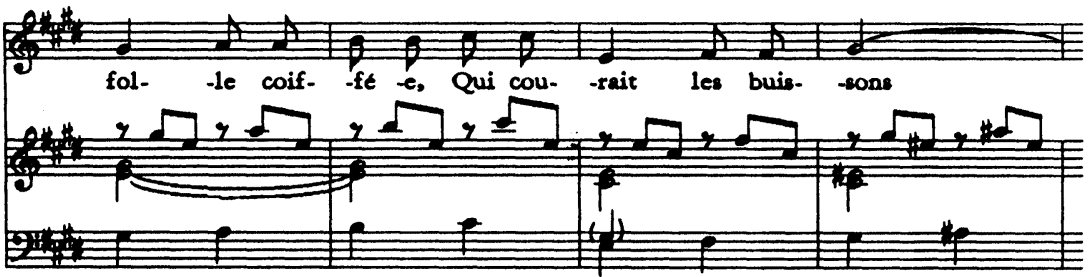

Example 1: $\mathrm{mm}$ 7-10

Measure 83 and 84 contain an emendation of the second type (Example 2). The original setting of the last two syllables of "infidèles" began with a sustained D\# extended from measure 83 through the first quarter note of measure 84 ; there is an erasure at the end of measure 84 which may well have been a B. There are a number of possible explanations for Fauré's decision to alter measure 84 to bring in the B on the downbeat. The most plausible is that while Fauré had decided on the phrase's ending with the motion from $D \#$ to $B$ (the better to anticipate the next phrase which begins with an ascending unfolding in the voice in measure 86), he determined subsequently that $\mathrm{a} D \#$ should not actually be present in the voice part in measure 84 where it might overshadow the voice exchange between $\mathrm{F \#}$ and D\# in the right hand of the accompaniment in this measure. Such an explanation would be consistent with Fauré's attention to the details of his compositions.

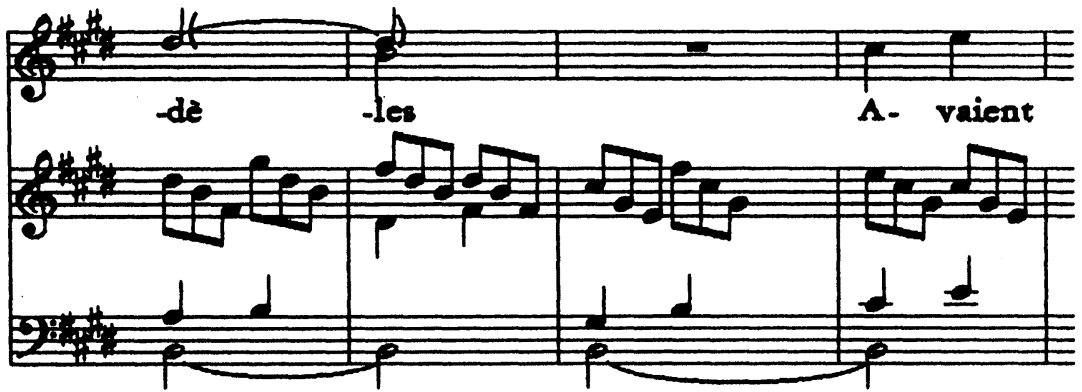

Example 2: $\mathrm{mm}$ 83-86

The third category of corrections consists of those which are bound up with an expression of the underlying structure of the song. This structure is represented in Example 3 in a reduced middleground sketch of the body of the song together with a rather more detailed sketching of the coda (measures 110 through 124). The structure of the piece is based on the varied repetition of one basic prolongation: the replication of the Ursatz with Kopfton 3. The fundamental 
line, 3-2-1, is replicated in the first stanza, measures 1-23. The second scale degree, $\mathrm{F} \#$, is prolonged by an upper neighbour note and a progression in the dominant key [V] V I, ${ }^{6}$ with the necessary alterations of E\# and A\#, as indicated in the sketch.

This structure is varied in a number of interesting ways in the setting of stanzas two and three from measures 24 through 61. First, the Kopfton is regained as scale degree 3 drawn from the minor mode, Gnatural; there is again a prefix prolongation of scale degree 2 supported by the dominant. This time, however, the progression within B major begins with the that key's Neapolitan (measure 28) and continues through an inversion of $\mathrm{V}^{\urcorner}$of $\mathrm{V}$ to bring in the dominant at measure 41 (whose arrival coincides with the end of the second stanza of text). The dominant (and the second scale degree) are then prolonged by the same progression used in the first stanza; note that the motion to the upper voice G\# in measure 53, now a complete upper neighbour to $\mathrm{F \# ,} \mathrm{escapes} \mathrm{middleground}$ fifths by inner voice motion supported by intervening harmonies (measures 4153). Note, too, the detail of the $A$ as incomplete upper neighbour to the larger neighbour, G\#.
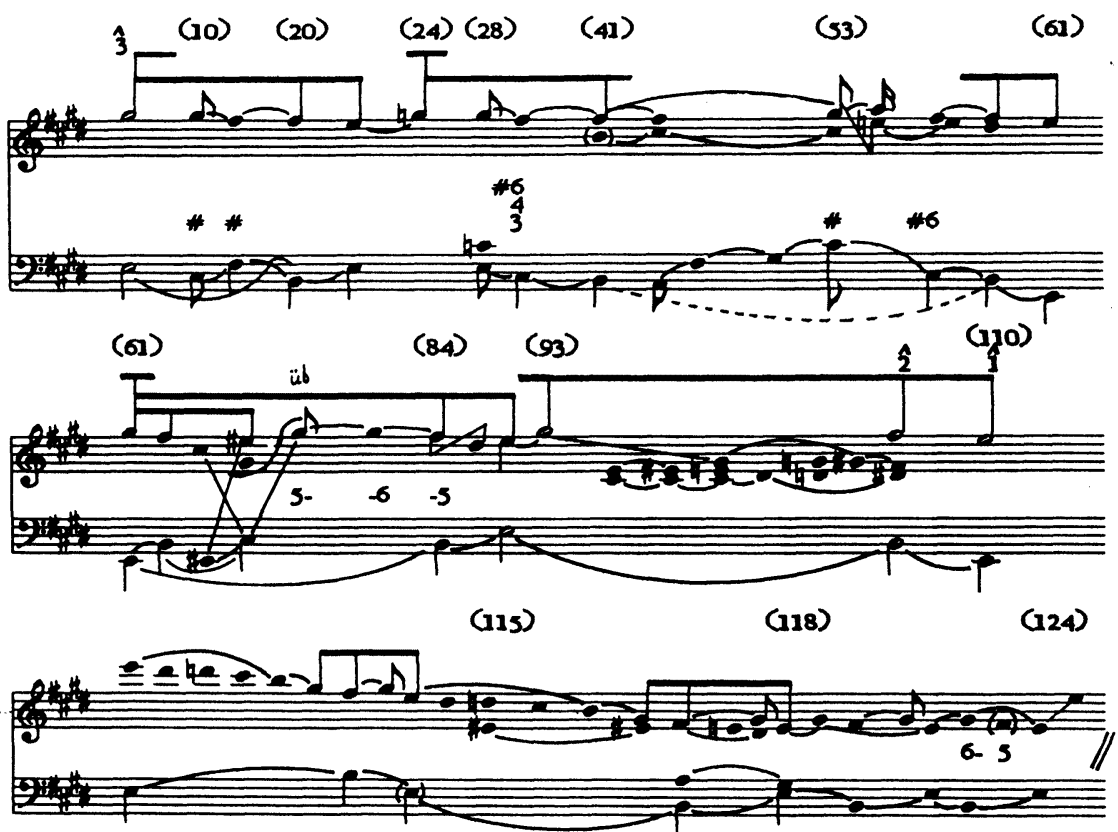

\section{Example 3}

${ }^{6}$ The analytical symbol, [V], indicates a secondary dominant of the harmony following (notation after Allen Forte). 
The basic pattern is further varied beginning in measure 61 . The replica descent

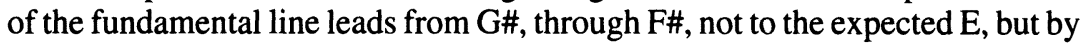
a melodic and harmonic ellipsis directly to $E \#$ supported by the $\mathrm{V}$ of $\mathrm{V}$ of the dominant. The main note is regained immediately afterward by a reaching over and continues to $\mathrm{F \#}$ over the dominant; however, $\mathrm{V}$ of $\mathrm{V}$ of the dominant proceeds directly to the dominant without the expected $\mathrm{V}$ of the dominant. Fifths between bass and upper voice are avoided not by the omitted harmony over a bass F\# but rather by a contrapuntal device, 5-6-5.

The fifth stanza begins in measure 93 with a motion regaining the main melodic note; the final descent is here prolonged with but a vestige of earlier structures. Here, the C\# major harmony whose prominence has increased throughout the piece becomes an ornament, a prolongation, of the tonic harmony itself. (The succeeding harmonic ellipses are diagrammed in Example 3.1). Further, this passage with various chromatic neighbour notes (one of which recalls fleetingly the minor Kopfton of measure 28) also contains several register transfers of the main note (only one is indicated in the sketch); register transfer and coupling of registers are an important textural feature throughout the piece.

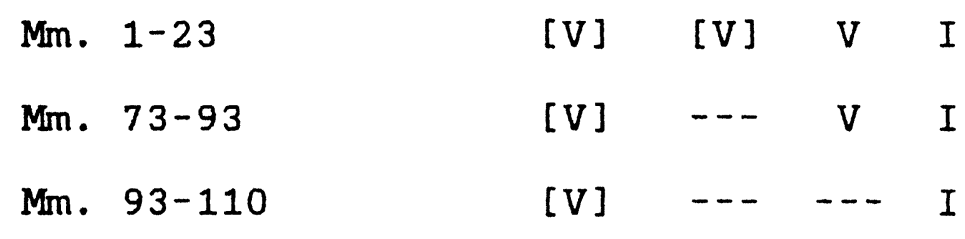

\section{Example 3.1}

Finally, the coda plays its usual role of confirming the piece's structure. The gapped upper voice descent of measures 110 to 112 serves to support the reading of $\mathrm{G \#}$ as the main melodic note; a linear progression down to the tonic is interrupted only by an upper neighbour to scale degree 2 in measure 113 , recalling the principal prolongational device of the song's structure and, specifically, the neighbour motion at measure 53 . The gapped descent begins again an octave lower, but the arrival of $\mathrm{G \#}$ is accompanied by E\# recalling the progression to the dominant at measure 84 . The end of the coda moves several times between I and V, but without resolving the appoggiatura 3 to 2; this emphasis on the resulting sixth over the bass at the expense of the expected fifth again recalls the passage leading to measure 84 and the 5-6-5 motion between outer voices at that point.

Consider now two changes in the manuscript. The first occurs at measures 102 and 103 (Example 4). The small brackets locate a crossing-out in the vocal line; the arrow indicates the place where the underlay has been changed: the last syllable of "immenses" was originally on the second beat of measure 103. The 
original note for the voice in measure 102 was $\mathrm{G \# ;} \mathrm{that} \mathrm{for} \mathrm{original} \mathrm{placement} \mathrm{of}$ the last syllable on the second beat of measure 103, A. It would appear that the G\# to A motion was replaced by the sustained B (or, possibly by B to A before a decision to sustain the $B$ and relocate the last syllable of the word). Fauré's motive in making this change can, of course, not be known absolutely, but a hypothesis presents itself. This harmony, as noted, has progressed from a subsidiary function within the key of the dominant ( $\mathrm{V}$ of $\mathrm{V})$ to a direct embellishment of the tonic chord (Example 3.1): the placing of B in the vocal line emphasizes that the harmony is indeed a dominant seventh and heightens the chord's effect. In support of this reading of Fauré's intentions is the fact that the $\mathrm{B}$ of the right hand of the accompaniment was, to judge from the relative fullness of the pen stroke, added after the rest of the piano part, perhaps at the same time the vocal line was altered.

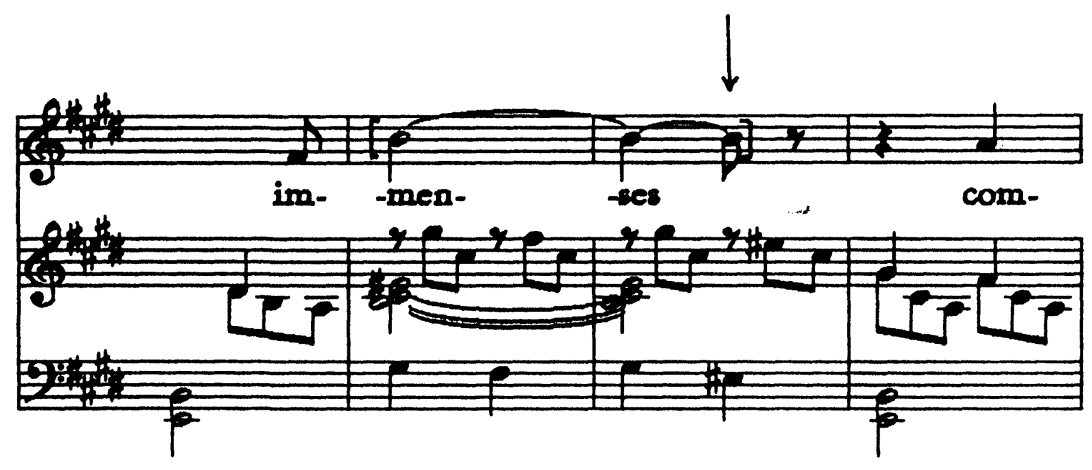

Example 4: mm. 101-104

Another example of the connection between alteration and structure occurs in measures 110 through 113. Example 5.1 is a reproduction of measures 110 and 111 in the manuscript while Example 5 is a reading of the layers of entry of the alterations.

Example 5a shows a reconstruction of the original situation which is the same as the published version of this passage as shown at Example 5d, but with one difference: there are no ties between the half note downbeat chords. As no ties have been erased in the manuscript, it would appear that at the point at which he would have written them, Fauré decided to alter the harmony. He erased the entire chord at the downbeat of measure 111, presumably to make room for the accidental which would be necessary: there would otherwise have been no reason to erase the lower D natural of the right hand. At this point, as well, the upper G\#'s (in the triplet figure) were erased and replaced by E\#'s which echo 


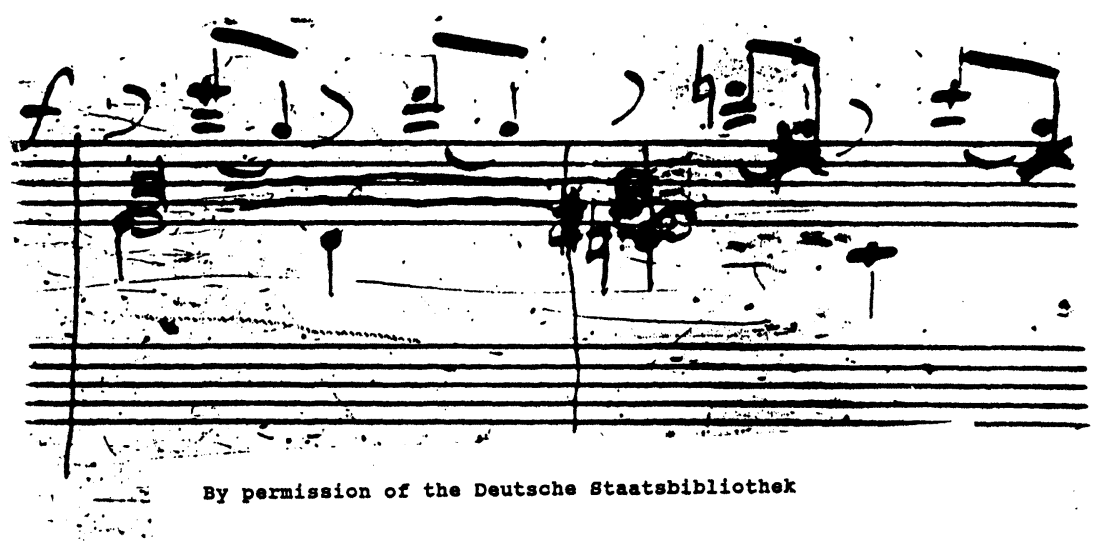

Example 5.1: mm. 110-111.

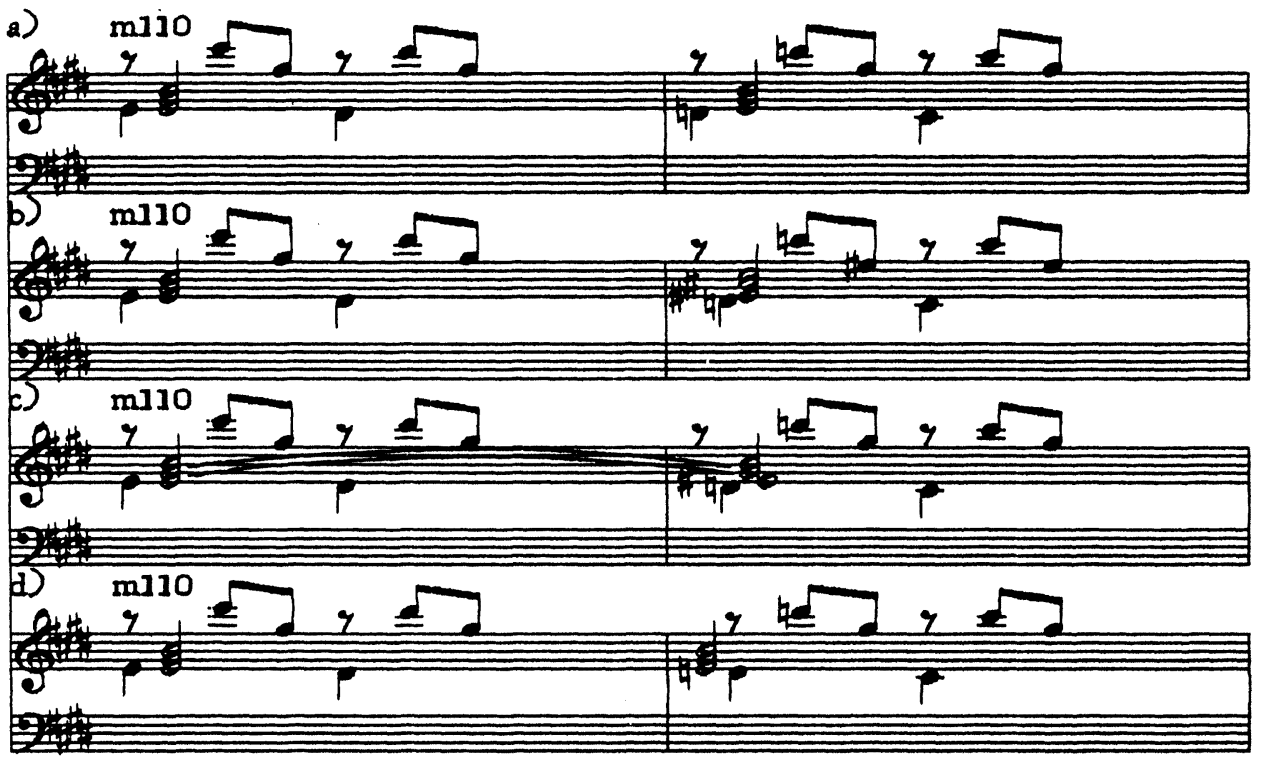

Example 5: mm. 110-111.

Example 5d) by permission of Alphonse Leduc 
the lower E\#, part of the harmony including the new A\# and C\# (Example 5b). It would appear that Fauré then reconsidered his change and elected to return, more or less, to the first version of the measure (Example 5c). The upper E\#'s were crossed out and replaced by G\#'s written over the erasures; A\# and C\# were erased (leaving a vestige of the A's \# between the bar line and the new vertical). As the E\# half note was to remain and as the paper was already wounded, Fauré did not change its position from the right to the left of the stem. The ties between the B's and G\#'s were now inserted. Sometimes later, probably at the page proof stage, the E\# became Enatural: this change is of some importance.

The changes in the next two measures, 112-113, are seen in two crossed-out measures (in manuscript at Example 6.1) and in erasures (in manuscript at Example 6.2).

Example $6 \mathrm{a}$ is a transcription of the discarded measures. Example $6 \mathrm{~b}$ represents an intermediate stage corresponding to the erasures visible in the surviving measures of Example 6.2. Changes (from $6 \mathrm{~b}$ to $6 \mathrm{c}$ ) include the alteration of

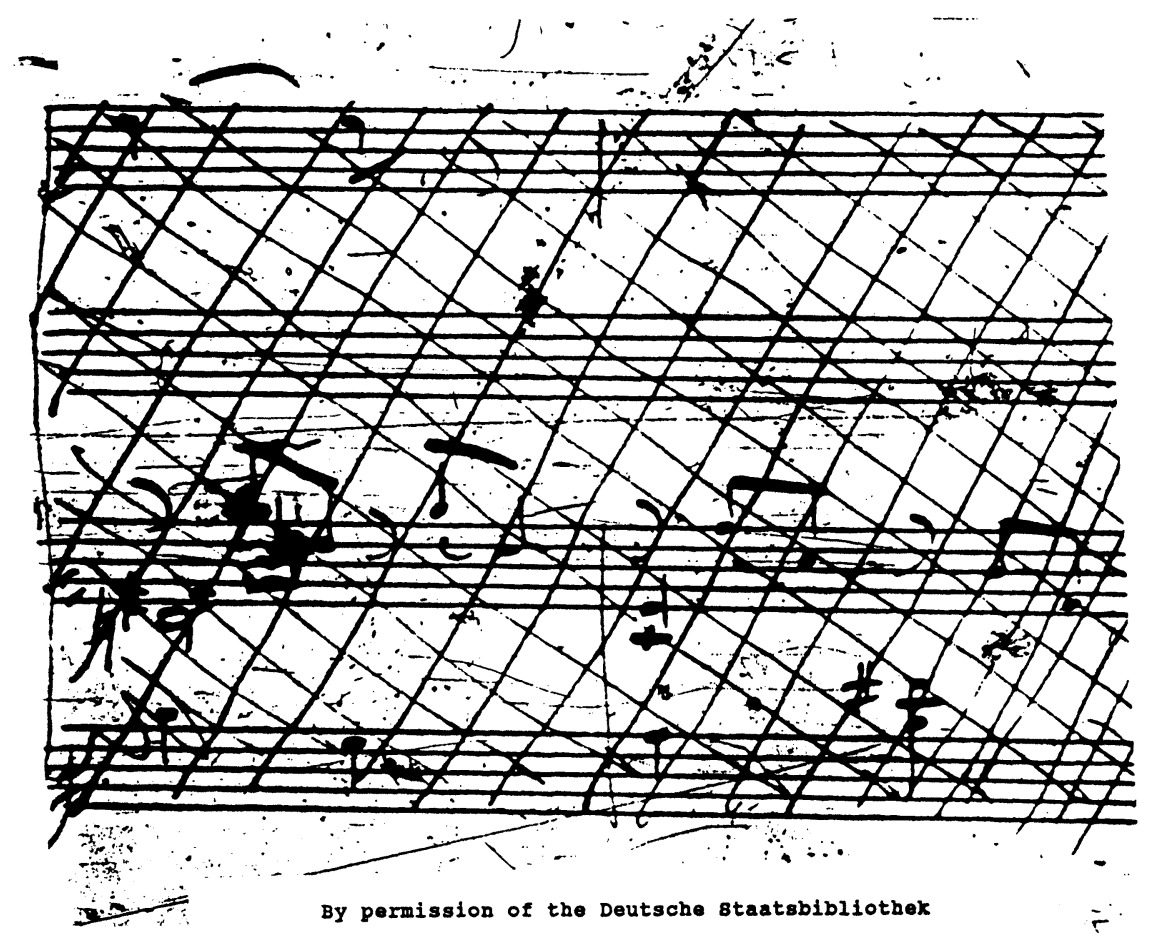

Example 6.1: mm. 112-113. 


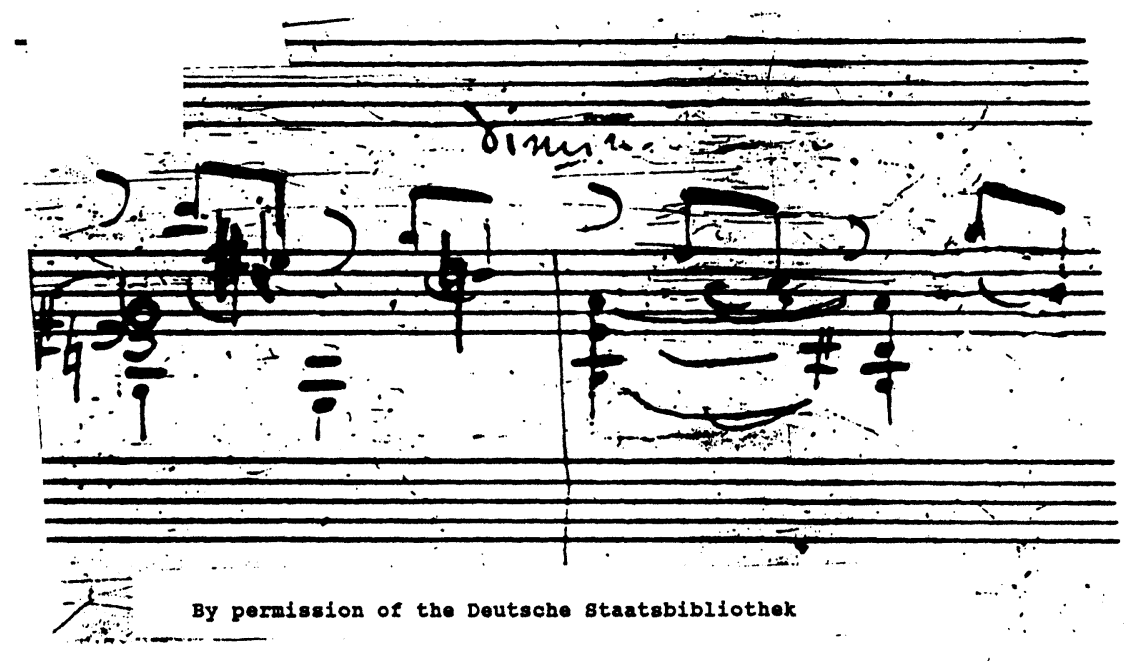

Example 6.2: $\mathrm{mm} .112-113$.

D natural to $E \#$ in the first triplet figure of $\mathrm{m} .112$; the $D$ note head is easily seen to be crossed out, the sharp for the E is written over the D's natural, and the change necessitates an extra natural crowded into the second beat triplet figure. The A of the first triplet figure of measure 113 was changed to C\# (see erasure, example 6.2); the A was then added to the quarter note verticals. (In support of this reading it can be noted that the part of the stem joining A to the vertical of beat 2 of measure 113 is a weaker pen stroke than the rest of the stem.) The G\# of measure 112 visible in Example 6.2 was added in pencil and may represent the last manuscript emendation in these measures. Again, importantly, the E\#'s were removed before publication, possibly in the page proofs. Fauré's concern for the coda is as characteristic as it is evident; there are further changes of detail in later measures here, and other songs with relatively few emendations sometimes have several versions of the postlude.

Fauré's general move toward more diatonic harmonies in the last few bars of this song (the elimination of E\#) is, also characteristically, not without definite reasons. In considering again the sketch of the coda in Example 3, it will be recalled that each echo of the descending third fundamental structure has a purpose: the first reiterates the main melodic note; in the final, published version, it is only the second restatement of the structure in measures 114-118 which reintroduces the chromaticism of E\# which plays such a varied and important role in the prolongational gestures of the piece. It would appear that Fauré finally decided that the introduction of this reference at the beginning of the song's postlude was precipitate-this reining in of a certain impatience to expose his 


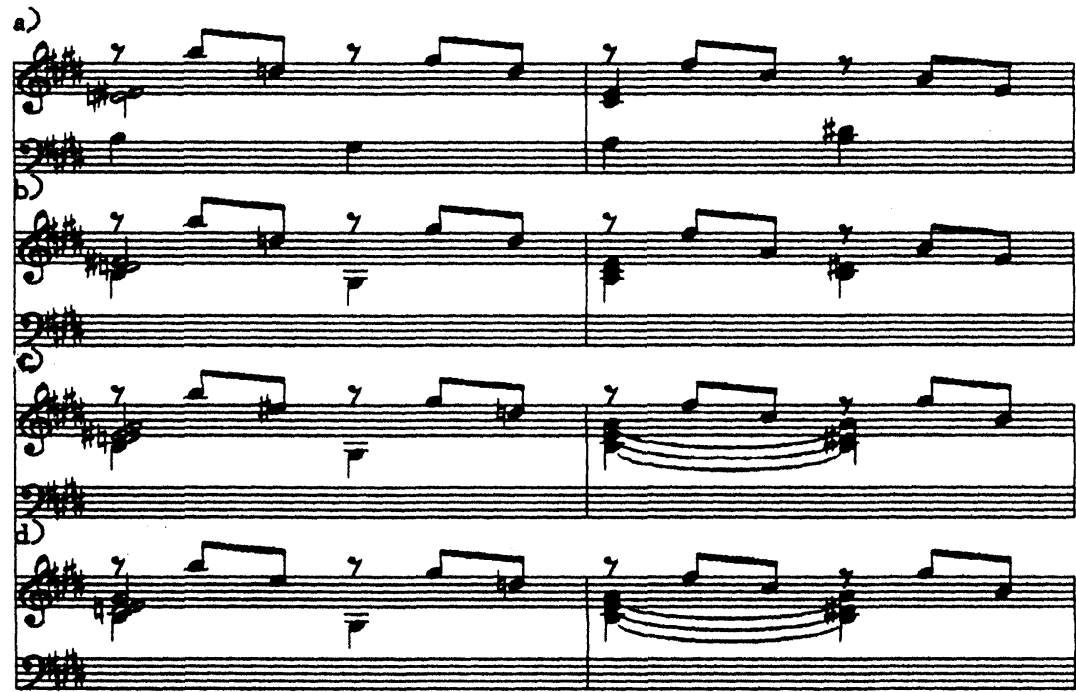

Example 6: mm. 112-113.

Example 6d) by permission of Alphonse Leduc

harmonic ideas is revealed by changes in other manuscripts and is, I believe, also characteristic of Fauré's compositional method.

The second item in the Deutsche Staatsbibliothek is not so noteworthy a discovery as the song manuscript, but does have a certain importance. When I inquired of the Berlin library what materials it possessed related to Fauré or to Lili or Nadia Boulanger, I was informed that the collection included a "Nachricht," or communication, from Boulanger to Fauré. I discovered that the library has made a slight error in its cataloging.

Faure died on the 4th of November, 1924; the next day, the arts newspaper, Comadia, devoted its front page to the composer including among the various stories about him a report of the circumstances of the death and an obituary. The paper indicated that no funeral arrangements had been made, but that, as part of these, his former students would hold a meeting the next morning. The next day's paper included an editorial calling for a state funeral for Fauré and a reannouncement of the student's meeting. The paper of Saturday, 7 November, included tributes from many important musicians: Charles-Marie Widor, d'Indy, Bruneau, Dukas, Pierné, Gigout, Vidal, Roussel, Aubert, Roger-Ducasse, Vuillemin, and Nadia Boulanger. The document in the Deutsche Staatsbibliothek is the autograph manuscript of Boulanger's tribute; how it came into the collection is uncertain-the library indicates that there is no record of its 
provenance and that it is what they refer to as "alter Bestand [old stock]."

The encomium covers four sheets of oblong, black-bordered note paper engraved at the upper right corner with Boulanger's address. It is clearly in her hand and is signed. Its language is formal in a way characteristic of Boulanger in such situations. The most striking passage is, I feel, the concluding sentence:

Aujourd'hui, alors que le cours en est interrompu, il nous semble en voir soudain mieux encore, l'ordre admirable, la radieuse certitude, le désintéressement total, l'incroyable simplicité, et nous ne savons plus ce qui domine en nous: l'admiration, la gratitude, ou la douleur.

It is fitting that a reference to Fauré's admirable order should share place with a piece that reveals that characteristic at work.

On 8 November, Comadia announced in the program for the funeral that Nadia Boulanger was to speak on behalf of Fauré's former students. On 9 November, the paper published an account of the funeral. Cardinal Dubois, the Archbishop of Paris, said mass; the President of the Republic and various other notables were in attendance; a number of people spoke-some speeches were reproduced-but Boulanger was not even mentioned in the list of attendees. This, which is a cruelly ironic reflection of the position Boulanger occupied in French musical circles for much of her life - that of outsider looking in-is also a symbol of what may be one of Fauré's most lasting but most hidden contributions to music and music history: his teaching. His pupils revered him and reveal his influence in their own music. For that reason, too, it is fitting that these two documents reside in the same place.

\section{REFERENCES}

McKAY, James

1982 "Le Trio Op. 120 de Fauré: Une esquisse inconnue de troisième mouvement." Études Fauréenes. No. 19, 9- 17.

NECTOUX, Jean-Michel

1980 "Gabriel Fauré." The New Grove Dictionary of Music and Musicians, ed. Stanley Sadie. London: 1980. Vol. 6, 417-428.

1980a Gabriel Fauré. Gabriel Fauré: Correspondance, ed. Jean-Michel Nectoux Paris: Flammarion, c. 1980.

1984 Gabriel Fauré. Gabriel Fauré: His Life Through His Letters, ed. Jean-Michel Nectoux, trans. J.A. Underwood. London and New York: Marion Boyars, 1984. [Translation of $1980^{\mathrm{a}}$, above.]

1990 Gabriel Fauré: Les Voix du Clair-Obscur. Paris: Flammarion, 1990.

ORLEDGE, Robert

1979 Gabriel Fauré. London: Eulenburg, 1979. 